\title{
HEALTH NEGLIGENCE OF GIRL CHILD IN KATHMANDU METROPOLITAN CITY
}

\section{Samidha Dhungel Pokharel}

\begin{abstract}
Along with right to food, shelter and education, children have also right to primary health regardless to their sex. Though the Government of Nepal has achieved the goal for reducing child mortality related to Millennium Development Goal. However still a large numbers of children especially girls are deprived of rights to health. This study is based on the oral reporting of purposively selected 269 parents including father and mother. Kathmandu Metropolitan city was taken into consideration during the year of 2013 to 2015. This study reveals that, more parents take their son to private health institutions and daughters to governmental health institutions. Similarly, this study has taken some socio-economic variables related to discrepancy of their son and daughter.
\end{abstract}

Key words: Son, daughter, health, facilities, parents, home

\section{INTRODUCTION}

According to UNICEF, gender equality means women and men, and girls and boys enjoy same rights, resources, opportunities and protections. Despite, most part of the world's ratification on CRC a large number of children are deprived of their rights. From infancy, girls face worse treatment than boys in such forms as selective malnutrition and denial of equal access to education and health services. The use of family planning is also driven by the birth of son. More mothers having sons with contrast to those having daughters are found to be stopping child birth permanently (Littleield, Murduch, \& Hashemi, 2003). Boys tend to have greater school attendance, higher likelihood of vaccination, and slightly longer breast feeding Though, Nepal has achieved the targets under MDG 4 - reducing the infant mortality rate (IMR) to 33 per 1,000 live births in 2014; reducing the under-five mortality rate (U5MR) to 38 per 1,000 live births in 2014; and increasing immunization against measles. It has a long way to go meeting the Sustainable Development Goal target for 2017, reducing under-5 mortality to 28 deaths per 1,000 live. There is also a need

* Dr. Pokherel is Associate Professor, Padma Kanya Multiple Campus, Bagbazar, TU. 
208 HEALTH NEGLIGENCE OF GIRL CHILD IN KATHMANDU ...

of addressing major inequalities within a number of population segments (Nepal Government, 2015).

From infancy, girls face worse treatment than boys in such forms as selective malnutrition and denial of equal access to health services. Gender bias in household spending health services provided to sons and daughters is more pronounced in poor and rural household who are dependent on agriculture (Nepal Government, 2011). Nepal living standard survey also reveals the fact that parents take their daughters in the government institutions for the consultation of acute illness whereas sons in the private institutions.

Table 1: Percentage of Health Consultations for Acute Illness by Type of Institution

\begin{tabular}{|c|c|c|c|c|c|c|c|c|c|c|c|c|}
\hline \multirow[b]{2}{*}{ Gender } & \multicolumn{6}{|c|}{ Government Institution } & \multicolumn{6}{|c|}{ Private Health Institution } \\
\hline & 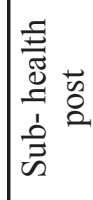 & 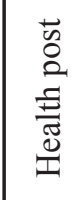 & 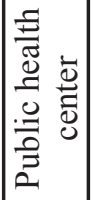 & 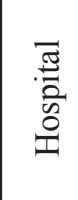 & 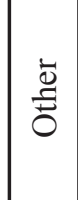 & $\begin{array}{l}\text { ज्ञ } \\
0 \\
0 \\
0 \\
0 \\
0\end{array}$ & 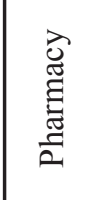 & 邑 & 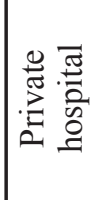 & 离 & $\begin{array}{l}\frac{\bar{\sigma}}{0} \\
0 \\
0 \\
0 \\
0\end{array}$ & 氶 \\
\hline Male & 12.3 & 7.8 & 2.1 & 11 & 2.2 & 35.3 & 25.6 & 28.8 & 5.2 & 5.1 & 64.7 & 100 \\
\hline Female & 13.7 & 8.0 & 2.9 & 11.6 & 2.3 & 38.5 & 25.0 & 26.3 & 5.4 & 4.8 & 61.5 & 100 \\
\hline
\end{tabular}

Source: NLSS, 2010/2011, Central Bureau of Statistics, November 2011. Vol. one

\section{OBJECTIVE AND METHODOLOGY}

Acknowledging the claim of scholars gender discrimination demolish with industrialization and increment of economic status of the family. The objective of this paper is to analyze the parental practices for health facilities provided to their sons and daughters sat home within the parameters of education, ethnicity and economic status.

According to Central Bureau of Statistics(CBS, 2012) majority of people living in Nepal are Hindu which covers 81.3 percent of a total population followed by Buddhist 9.0 percent, Islam 4.4 percent, Kirat 3.1 percent, Christianity 1.4 percent, Prakriti 0.5 percent; and others like Bon, Jain, Sikh, Bahai are less than 0.05 percent. Similarly, the total of 1,744,240 people resides in Kathmandu district, out of which 1,395,538 (80 \%) are 
Hindu, 268,479 (15\%) Buddhist, 40,592 (2.32\%) Christian, and 21,866 $(1.25 \%)$ are Islam. The number of people falling under other religion like: Kirat, Prakriti, Jain, Sikh, Bahai, and Bon residing in Kathmandu district is less than 1 percent. Considering the density of people categorized according to religion, this study is focused on two major religious groups: Hindu and Buddhist population. In Nepalese society it has been reported that one in every four household $(25.42 \%)$, at least one member is absent and living outside the country; the highest proportion (44.81\%) of absentee falls under the age between 15-24 years old. In such condition household survey through probability sampling was very costly, and time consuming. Acknowledging the complexity of society, this study had taken 269 respondents including father and mother having both son and daughter purposively. People from different ethnicity, educational, and professional background were purposively selected.

In the beginning, person who was in personal contact and met the criteria were chosen as respondents for data collection then respondents were requested to refer other people who were qualified as respondents. Respondent's first cousins were excluded to avoid biasness and to get more diverse data. Thus respondents were identified through personal net working which already has been used by Kaber (2003). This study had paid special attention to include more diverse respondents in terms of caste, educational status, economic groups, occupation, and religion as well. Out of thirty-five wards, the respondents were covered from twenty-three different wards. Reducing child mortality rate is one of the Millennium Development Goals to be achieved by 2015 . Health facilities provided to children influence the health status of children. Nepal Family Health Program (2007) shows slighter gender disparity in receiving the basic vaccine in rural areas of Nepal, which is 87 percent of female children against 91 percent of male children get full dose of vaccine. Likewise the number of male children (37\%) getting vaccination is higher than those of female children $(24 \%)$. Six percent of female children versus two percent male children never receive vaccine (Nepal Family Health Program II, 2010). Assuming parents may show gender differentiated behavior during selecting the types of institutions for treatment. This study also has considered the places where parents take their children for the treatment. 
210 HEALTH NEGLIGENCE OF GIRL CHILD IN KATHMANDU ...

\section{DISCUSSION AND RESULT}

Verbally recorded data of this study about the place, where parents take their son and daughter for treatment also shows parental gender differentiated behavior while providing health services. In general, more sons in comparison to daughters $(29.8 \%$ versus $23.2 \%)$ were treated in clinics and (45.6\% versus $37.4 \%)$ in hospitals respectively. On the other hand, more daughters with compared to sons (16.8\% versus $7.0 \%)$ respectively were treated with either homemade local medicine. The number of daughters taken to the pharmacy locally known as medical shop and treated with 'over the counter drug' was greater than sons which was 8 percent versus 7 percent respectively. In general, the significant difference between type of health facilities provided and gender of the children had been observed at 0.016 levels.

However, demographical categorization of data reveals the differences within ethnicity, religious group, economical groups and educational groups. According to ethnically split data, more girls than boys from Newar families were treated with either home-made medicine or medicines locally available in medical shops (Pharmaceuticals); and sons are taken to the hospitals and clinic to diagnosed and treated with the medicines recommended by doctors. Significant difference was observed to be at $\mathrm{p}=0.086$ level. Similar types of differences were reported by the parents belonging to Buddhist and low income group and illiterate and parents attending up to class seven. The significant differences observed within these groups were Buddhist $-\mathrm{p}=0.086$ level; parents with income 20000 or less $-\mathrm{p}=0.023$ level and parents who were illiterate or have attained up to class seven $-p=0.058$ level. Parental negligence toward daughters; medical care might be one of the reason that make girl child vulnerable and forced to hospitalized. One of the students studying in Child Development and Gender Socialization in Master level and concurrently working in a Hospital as a nurse shared her observation as "Parents bring their sons to hospital before they become serious. So, boys go back to their own home after medical checkup in out-patient ward. But parents bring their daughters to the hospital when they become serious and are admitted in hospital. Therefore, one can see more girls than sons lying down in hospital's bed". 
Table 2: Gender of the Child and Health Facilities

\begin{tabular}{|c|c|c|c|c|c|c|c|}
\hline & & \multirow[b]{2}{*}{$\begin{array}{l}\text { Gender } \\
\text { of the } \\
\text { children }\end{array}$} & \multicolumn{4}{|c|}{ Types of health facilities } & \multirow[b]{2}{*}{ 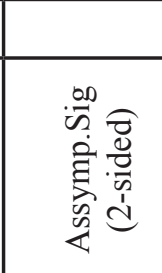 } \\
\hline & & & $\begin{array}{l}\tilde{U} \\
\tilde{\Xi} \\
\tilde{\Xi} \\
0 \\
0 \\
0 \\
0\end{array}$ & 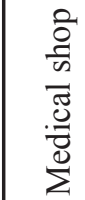 & 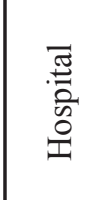 & 弟 & \\
\hline \multirow{2}{*}{\multicolumn{2}{|c|}{ Over all }} & Son & 7.0 & 17.5 & 45.6 & 29.8 & \multirow{2}{*}{$\begin{array}{l}X^{2}=10.309 \\
P=0.016\end{array}$} \\
\hline & & Daughter & 16.8 & 22.6 & 37.4 & 23.2 & \\
\hline \multirow{6}{*}{$\begin{array}{l}\text { Ethnic } \\
\text { Group }\end{array}$} & \multirow{2}{*}{$\begin{array}{l}\text { Caste } \\
\text { Group }\end{array}$} & Son & 8.2 & 16.5 & 50.6 & 24.7 & \multirow{2}{*}{$\begin{array}{l}X^{2}=2.206 \\
P=0.531\end{array}$} \\
\hline & & Daughter & 14.1 & 17.9 & 41.0 & 26.9 & \\
\hline & \multirow{2}{*}{ Newar } & Son & 4.9 & 17.1 & 39.0 & 39.0 & \multirow{2}{*}{$\begin{array}{l}X^{2}=6.608 \\
P=0.086\end{array}$} \\
\hline & & Daughter & 22.2 & 22.2 & 33.3 & 22.2 & \\
\hline & \multirow{2}{*}{ Hill } & Son & 6.7 & 20. & 42.2 & 31.1 & \multirow{2}{*}{$\begin{array}{l}X^{2}=5.243 \\
P=0.155\end{array}$} \\
\hline & & Daughter & 17.1 & 31.7 & 34.1 & 17.1 & \\
\hline \multirow{4}{*}{ Religion } & \multirow{2}{*}{ Hindu } & Son & 7.4 & $\mid 17.6$ & 51.9 & 23.1 & \multirow{2}{*}{$\begin{array}{l}X^{2}=4.245 \\
P=0.236\end{array}$} \\
\hline & & Daughter & 15.5 & 20.6 & 42.3 & 21.6 & \\
\hline & \multirow{2}{*}{ Buddhist } & Son & 6.5 & 17.7 & 33.9 & 41.9 & \multirow{2}{*}{$\begin{array}{l}X^{2}=7.129 \\
P=0.068\end{array}$} \\
\hline & & Daughter & 19.0 & 25.9 & 29.3 & 25.9 & \\
\hline \multirow{6}{*}{$\begin{array}{l}\text { Income } \\
\text { Group }\end{array}$} & \multirow{2}{*}{$\begin{array}{l}20,000 \\
\text { or less }\end{array}$} & Son & 1.7 & 25.9 & 53.4 & 19.0 & \multirow{2}{*}{$\begin{array}{l}X^{2}=9.487 \\
P=0.023\end{array}$} \\
\hline & & Daughter & 17.3 & 30.8 & 36.5 & 15.4 & \\
\hline & \multirow{2}{*}{$\begin{array}{l}20,001- \\
40,000\end{array}$} & Son & 10.4 & 14.9 & 43.3 & 31.3 & \multirow{2}{*}{$\begin{array}{l}X^{2}=1.947 \\
P=0.583\end{array}$} \\
\hline & & Daughter & 11.3 & 22.6 & 43.5 & 22.6 & \\
\hline & \multirow{2}{*}{$\begin{array}{l}40,001 \\
\text { or above }\end{array}$} & Son & 9.3 & 11.6 & 39.5 & 39.5 & \multirow{2}{*}{$\begin{array}{l}X^{2}=2.033 \\
P=0.566\end{array}$} \\
\hline & & Daughter & 19.4 & 13.9 & 30.6 & 36.1 & \\
\hline \multirow{6}{*}{$\begin{array}{l}\text { Educational } \\
\text { Status }\end{array}$} & \multirow{2}{*}{ Below 7} & Son & 5.6 & 25.9 & 48.1 & 20.4 & \multirow{2}{*}{$\begin{array}{l}X^{2}=7.470 \\
P=0.058\end{array}$} \\
\hline & & Daughter & 18.2 & 38.6 & 38.8 & 11.4 & \\
\hline & \multirow{2}{*}{$8-12$} & Son & 5.6 & 15.3 & 47.2 & 31.9 & \multirow{2}{*}{$\begin{array}{l}X^{2}=3.306 \\
P=0.347\end{array}$} \\
\hline & & Daughter & 12.5 & 20.3 & 43.8 & 23.4 & \\
\hline & \multirow{2}{*}{$\begin{array}{l}\text { BA and } \\
\text { above }\end{array}$} & Son & 11.4 & 11.4 & 40.9 & 36.4 & \multirow{2}{*}{$\begin{array}{l}\mathrm{X}^{2}=1.773 \\
\mathrm{P}=0.621\end{array}$} \\
\hline & & Daughter & 21.7 & 10.9 & 34.8 & 32.6 & \\
\hline
\end{tabular}

Source: Field survey 2013-2015. 
212 HEALTH NEGLIGENCE OF GIRL CHILD IN KATHMANDU ...

Data was further categorized to identify the age of the children getting health facilities differently. For this purpose, age of the children was categorized into three groups: birth to less than 5 years, 5-12 years and 13 to 19 years old based on the developmental stages of children. Table 3 reveals outrageous status of daughters below five years. A total of 32.1 percent daughters against 2.8 percent son under five years survive with home-made medicine and 73.3 percent sons against 26.7 percent daughters were taken to clinic (private institution) generally known as best place for treatment in Kathmandu. Significant differences observed in 0-5 years group was at $p=00.007$ level. Preference of sons against daughters for providing better health facilities continues until they reach the age twelve. More daughters i.e. 16.9 percent against son 1.6 percent were treated with home-made medicines. Likewise, the number of sons treating in clinic was found to be 36.5 percent against 21.5 percent for daughters. Significant difference in the types and place selection for sons and daughters was observed to be at $\mathrm{p}=0.008$ level. But as sons and daughters enter the teen age, reverse gender gap in types and place selection for their treatment was observed. Instead of taking sons to hospital or clinic, parents take care of their son $(14.1 \%)$ at home with home-made medicines. On the contrary, though insignificant, less number $(9.5 \%)$ of teenage daughters were taken care at home. Likewise, though insignificant in number more daughters $(30.2 \%)$ against son $(23.9 \%)$ were taken into clinics to identify their health problems and treated accordingly. Findings of this study has raised some questions: Do parents are more concerned with sons' health and take care of teenage boys for minor health problems like cough and cold but neglect daughters for same health problems? Is it that parental negligence towards daughters worsens the case and parents are compelled to take their daughters to the clinics? Do girls get more severe health problems than that of boys during teen age? 
Table 3: Types of Treatment to the Children During Different Age

\begin{tabular}{|c|c|c|c|c|c|}
\hline Age group & $\begin{array}{l}\text { Types of } \\
\text { treatment }\end{array}$ & $\begin{array}{l}\text { Gender of } \\
\text { children }\end{array}$ & Number & Percentage & $\begin{array}{c}\text { Assymp. } \\
\text { Sig(2- } \\
\text { sided) }\end{array}$ \\
\hline \multirow{8}{*}{$\begin{array}{l}0-5 \text { years } \\
\text { old } \\
\text { Total }=64\end{array}$} & \multirow{2}{*}{ House made } & Son & 1 & 2.8 & \multirow{8}{*}{$\begin{array}{l}\mathrm{X}^{2}=12.124 \\
\mathrm{P}=0.007\end{array}$} \\
\hline & & Daughter & 9 & 32.1 & \\
\hline & \multirow{2}{*}{ Medical Hall } & Son & 3 & 8.3 & \\
\hline & & Daughter & 4 & 14.3 & \\
\hline & \multirow{2}{*}{ Hospital } & Son & 21 & 58.3 & \\
\hline & & Daughter & 11 & 39.3 & \\
\hline & \multirow{2}{*}{ Clinic } & Son & 11 & 73.3 & \\
\hline & & Daughter & 4 & 26.7 & \\
\hline \multirow{8}{*}{$\begin{array}{l}6-12 \text { years } \\
\text { old } \\
\text { Total= } \\
128\end{array}$} & \multirow{2}{*}{ House made } & Son & 1 & 1.6 & \multirow{8}{*}{$\begin{array}{l}X^{2}=11.634 \\
P=0.009\end{array}$} \\
\hline & & Daughter & 11 & 16.9 & \\
\hline & \multirow{2}{*}{ Medical hall } & Son & 13 & 20.6 & \\
\hline & & Daughter & 18 & 27.7 & \\
\hline & \multirow{2}{*}{ Hospital } & Son & 26 & 41.3 & \\
\hline & & Daughter & 22 & 33.8 & \\
\hline & \multirow{2}{*}{ Clinic } & Son & 23 & 36.5 & \\
\hline & & Daughter & 14 & 21.5 & \\
\hline \multirow{8}{*}{$\begin{array}{l}13-19 \\
\text { years old } \\
\text { Total= } \\
134\end{array}$} & \multirow{2}{*}{ House made } & Son & 10 & 14.1 & \multirow{8}{*}{$\begin{array}{l}X^{2}=1.129 \\
P=0.770\end{array}$} \\
\hline & & Daughter & 6 & 9.5 & \\
\hline & \multirow{2}{*}{ Medical hall } & Son & 14 & 19.7 & \\
\hline & & Daughter & 13 & 20.6 & \\
\hline & \multirow{2}{*}{ Hospital } & Son & 30 & 42.3 & \\
\hline & & Daughter & 25 & 39.7 & \\
\hline & \multirow{2}{*}{ Clinic } & Son & 17 & 23.9 & \\
\hline & & Daughter & 19 & 30.2 & \\
\hline
\end{tabular}

Source: Field survey 2013-2015

The high rate of female mortality rate in South Asian Countries is associated with intra-household discrimination in receipt of medical attention. With the analysis of $52^{\text {nd }}$ Indian National Sample Survey, which collected for the first time detailed verbal autopsies of deceased person, had observed high level of intra-household gender discrimination in health care decision of household. They indicated that boys were found to be hospitalized before their death, but girl children especially infants were discriminated and deprived of medical facilities before they die. The difference between genders of the child dying in hospital was statistically 


\section{HEALTH NEGLIGENCE OF GIRL CHILD IN KATHMANDU ...}

significant. The place of death whether a person get medical assistance immediately before his or her death was used as health indicator for this study.

Finding of this study is consistent and supports the assumption that parent show gender discriminatory behavior in the provision of health of son and daughter and similarly consistent with the report of Nepal Living Standard Survey which unravel the fact that more parents take their daughter to government health institutions such as sub-health post, health post, public health center and hospital, whereas son to private health institutions such as pharmacy, clinic, private hospitals. Likewise, this study also supports gender discrimination demolishes with industrialization and increment of economic status of the family.The fact revealed based on age group categorization of children that as children get older the gender gap reverse in distribution of health facilities was a mystery that could be solved only from further studies.

\section{CONCLUSION}

Gender bias in health service is not only an issue of specific group rather an issue of nation as a whole. Girl child, residing in Kathmandu Metropolitan City which is also kingdom of Nepal, were found to be discriminated from their basic health rights against their male counterparts. Hence it could be concluded that minimization of gender gap in health facilities basically depends on improvements of parental education and economic status.

\section{WORKS CITED}

CBS, (2012). Population census report. Kathmandu: Government of Nepal.

Kabeer, N. (2003). Assessing the 'wider' social impacts of microfinance services: Concepts, methods, findings. IDS Bulletin , 34 (4), pp. 106- 114.

Littleield, E., Murduch, J., \& Hashemi, S. (2003). Is microfinance an effective strategy to reach the millennium development goals. Focus Note (24)., CGAP.

Nepal Family Health Program (2007), Annual report 2063/64. Kathmandu: Nepal Government.

Nepal Government (2015). Nepal and the millennium development goals, final status report, Nepal. Kathmandu: Government of Nepal.

- - - (2011, 2012). The Nepal living standard survey. Kathmandu: CBS. 